\title{
Crude-Oil-Spill-Induced Spatial Variation in Woody Species Populations of an Oil-Rich Community in Rivers State, Nigeria
}

\author{
Uzoma Darlington Chima (Corresponding author) \\ Department of Forestry and Wildlife Management, \\ Faculty of Agriculture, University of Port Harcourt, Nigeria \\ Tel: 234-803-812-1887Ｅ-mail: uzoma.chima@uniport.edu.ng \\ Giobari Vure \\ Department of Forestry and Wildlife Management, \\ Faculty of Agriculture, University of Port Harcourt, Nigeria \\ E-mail: giobarivure@yahoo.com
}

Received: August 1, 2013 Accepted: August 20, $2013 \quad$ Published: October 25, 2013

doi:10.5296/jee.v4i2.4082ＵRL: http://dx.doi.org/10.5296/jee.v4i2.4082

\begin{abstract}
We used the spatial analogue technique of studying ecosystem dynamics to evaluate the impact of crude oil pollution on species composition and populations of woody plants in an oil-producing community in Ogoniland located within the Niger Delta Region of Nigeria. Three sites - Unpolluted Site (US), Polluted/Treated Site (PTS) and Polluted/Untreated Site (PUS), were purposively selected for the study. Five $35 \mathrm{~m}$ x $35 \mathrm{~m}$ quadrats were randomly laid in each of the sites for woody species enumeration. Woody species diversity was measured using Shannon-Wiener diversity index $\left(\mathrm{H}^{\prime}\right)$. Species richness was calculated using Margalef index (R); while similarity in species between sites was measured using Sorensen index (SI). A total of 2166 individuals belonging to 28 species and 16 families were recorded in US; 149 individuals belonging to 14 species and 11 families were recorded in PTS; while 72 individuals belonging to 7 species and 7 families were recorded in PUS. Species diversity was higher in US $\left(\mathrm{H}^{\prime}=2.917\right)$ than in PTS $\left(\mathrm{H}^{\prime}=2.406\right)$ and PUS $\left(\mathrm{H}^{\prime}=1.801\right)$. Species richness was also higher in US $(\mathrm{R}=3.515)$ than in PTS $(\mathrm{R}=2.598)$ and PUS $(\mathrm{R}=1.403)$.
\end{abstract}


Similarity in species composition was higher between US and PTS (SI $=0.48)$ than between US and PUS (SI = 0.34), and highest between PTS and PUS (SI = 0.67). The results showed that crude oil pollution has impacted negatively on woody species of the community. However, higher species richness and diversity in PTS than in PUS, and higher similarity in species composition between US and PTS than between US and PUS, underscores the relevance of proper remediation for the regeneration and restoration of the woody species of the area.

Keywords: Ogoniland, Crude oil spillage, Remediation, woody species, Abundance, Diversity 


\section{Introduction}

The Nigerian economy to a very large extent depends on crude oil sales. In Nigeria, the Oil and Gas sector plays a very dominant role to the economy in that 90 percent of the total revenue comes from Oil and Gas production while over 90 percent of the nation's foreign exchange earnings comes from the sales of crude oil (http://www.nnpcgroup.com). This oil is mainly found within the Niger Delta Region of Nigeria - a region that is made up of nine States including Rivers State. In Rivers State is found the Ogoniland - an area endowed with immense crude oil reserves, first discovered at Bomu, Kegbara- Dere, in Gokana Local Government Area in 1958 after Oloibiri, by Shell Petroleum Development Company (SPDC) (Tanee and Albert, 2011). Although, SPDC has not produced oil or gas from Ogoni fields since 1993, major oil pipelines still pass through Ogoniland and oil spills continue to affect the region, due to lack of maintenance and vandalisation of oil infrastructure and facilities.

Evidences of oil spills are apparent in Ogoniland. Between 1993 and mid- 2007, 35 incidences of oil spills were recorded, outside unnoticed slicks and unreported cases (Pyagbara, 2007). Tanee and Albert (2011) reported that popular cases of crude oil spills in Ogoniland include the Bomu Oil Well 2 of 1970 which polluted over 607 hectares of farmland belonging to Kegbara- Dere, and Kegbara-Dere crude oil seepage of 2008 from one of Trans-Niger crude oil pipelines that cross the community.

It is well known that hydrocarbons are harmful to animals and plants (Dorn and Salanitro, 2000). Many workers have reported the impact of crude oil pollution on plants. Michel et al. (2002, 2005) observed that petroleum constitutes a pollutant that can persist in the environment for a long period until the vegetation recovers completely, and that its persistence can be explained by the slow biodegradation of hydrocarbons. Oil contamination causes slow rate of germination in plants (Ogbo et al, 2009); and this has been attributed to the prevention or reduction of the seeds' access to water and oxygen due to the physical barrier caused by oil (Adam and Duncan, 2002). Crude oil spill has also been reported to reduce species number and live standing herbaceous crop biomass (Debojit and Sarma, 1996); retard and reduce percentage seed germination, plant height, stem density, photosynthetic rate and biomass, and in most cases cause outright death of plants (Qianxin and Mendelssohn, 1996; Pezeshki et al., 2000; Ekundayo et al., 2001; Tanee and Anyanwu, 2007; Anyanwu and Tanee, 2008).

Environmental pollution in Ogoniland from oil spills remains largely untreated or partially remediated. Despite the bogus claims by the oil companies with regards to remediation, recent UNEP report found 10 of the 15 sites investigated, which SPDC claimed remediated, to contain pollutants exceeding SPDC and government standards. As aptly observed by Adeyemo (2008), "it is uncontroversial to conclude that the Niger Delta Region is environmentally degraded by oil and gas exploration and exploitation activities but our conclusions could not be supported quantitatively because of shortage of relevant data". Therefore, this study was undertaken to quantitatively ascertain the impact of crude oil pollution on populations of woody species in Kegbara-Dere community within Ogoniland, and the effectiveness of the remediation carried out with respect to woody plant species 


\section{Macrothink}

regeneration. Specifically, it examined and compared woody plant species in unpolluted, polluted/treated, and polluted/untreated sites.

2. Materials and Methods

\subsection{Study Area}

Kegbara-Dere is located in Gokana Local Government Area of Rivers State. The town is basically linear. This pattern is as a result of the direction of expansion of the town northwards and southwards. It lies in the humid tropical zone with annual rainfall that ranges from $2000-2470 \mathrm{~mm}$, and an annual temperature ranging from $23^{\circ} \mathrm{C}$ minimum to $32^{\circ} \mathrm{C}$ maximum (NDES, 2001). Generally, the vegetation of the area is made up of an intricate mixture of plants which belong to different plant families, genera, and species. A Port Harcourt Appeal Court Report (1994) observed that the soils in the polluted areas are acidic, poor in total nitrogen, available phosphorous, organic carbon; have high bulk densities, high level of manganese, low levels of exchangeable cations, low hydraulic conductivities and infiltration capacities; and consequently, very poor plant growth.

\subsection{Selection of Study Sites}

Three sites were used for the study. The first site which served as the reference ecosystem $\left(4^{0}\right.$ $39^{\prime} 8^{\prime \prime} \mathrm{N}$ and $7^{0} 14^{\prime} 26 " \mathrm{E}$ ) was selected from an unpolluted area (about $5 \mathrm{~km}$ away from the Kegbara-Dere/Bomu Oil Field). The second site ( $4^{0} 39^{\prime} 37^{\prime \prime} \mathrm{N}$ and $7^{0} 15^{\prime} 8$ "E) was selected from a polluted but treated or remediated area; while the third site $\left(4^{0} 39^{\prime} 411^{\prime \prime} \mathrm{N}\right.$ and $\left.7^{0} 15^{\prime} 6^{\prime \prime} \mathrm{E}\right)$ was selected from a polluted and untreated area. The remediation carried out at the polluted/treated site included manual tillage and bulking of soil; and this was done in 2007 2008. These sites were chosen to ascertain the impact of crude oil pollution on the woody species, and the effectiveness of the remediation exercise carried out. Figure 1 is the map of Rivers State showing the study sites. 


\section{$\Delta$ Macrothink}

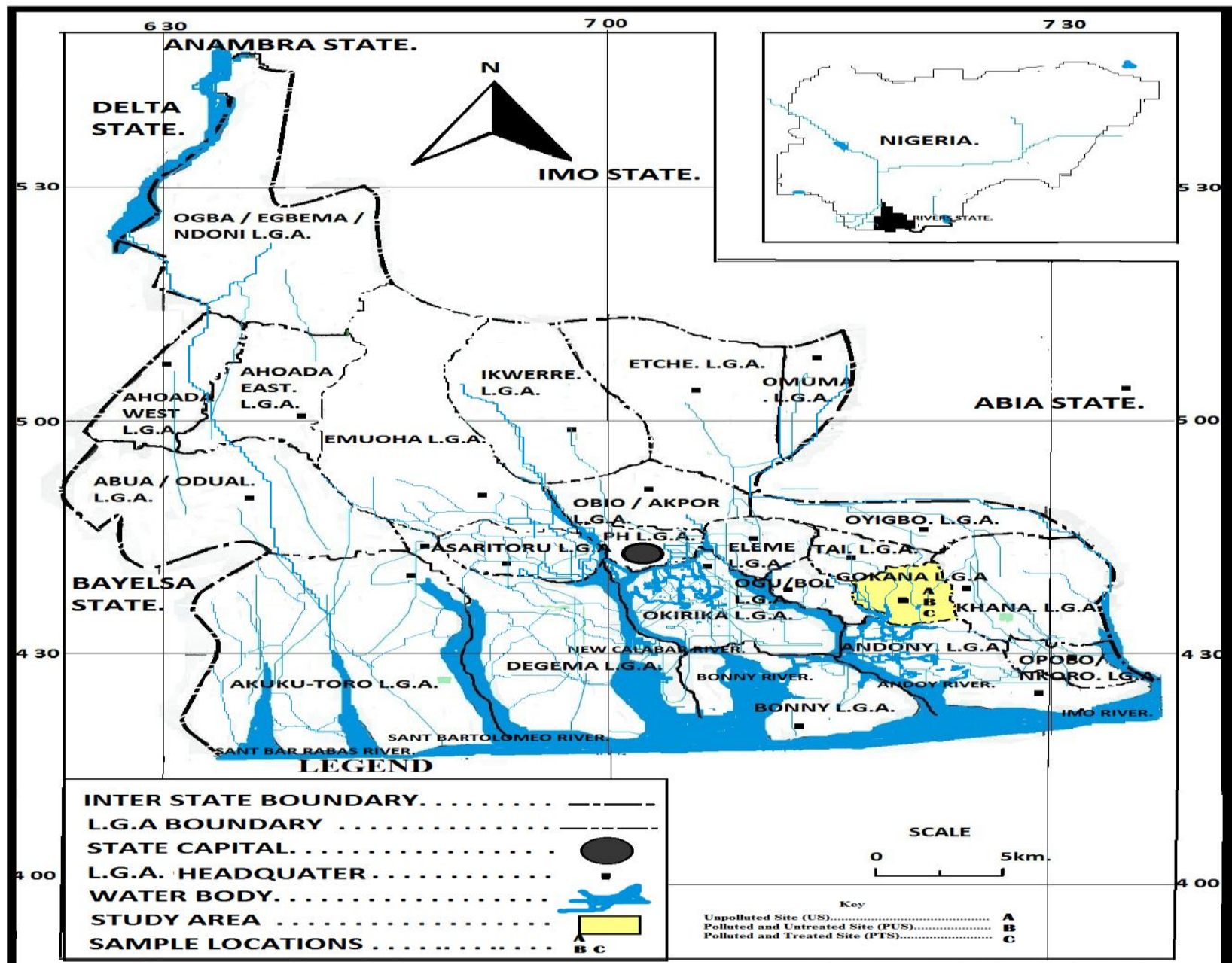

Figure 1. Map of Rivers State showing the Study Sites

Source: Rivers State Ministry of Land and Urban Planning

\subsection{Woody Species Enumeration}

Five $35 \mathrm{~m} \times 35 \mathrm{~m}$ quadrats were randomly laid in each of the sites for woody species enumeration. This quadrat size falls within the range specified in literature for ecological studies in the humid tropics (Salami 2006). Narrow cut lines, ropes and pegs, were used to demarcate plot boundaries. Species identification was done with the aid of the keys provided by Keay (1989), and Hutchinson and Dalziel (1954). All woody species with a minimum height of $1.5 \mathrm{~m}$ were identified to species level and the number of individuals counted for each site.

\subsection{Data Analysis}

\subsubsection{Woody Species Diversity}

Woody species diversity was calculated for each site using the Shannon- Wiener Diversity Index as described by Kent and Coker (1992).

$\mathrm{H}^{\prime}=-\sum_{i=1}^{s}$ pi ln pí 
Where:

$\mathrm{pi}=\mathrm{ni} / \mathrm{N}$

$\mathrm{ni}=$ Total number of individuals belonging to ith species

$\mathrm{N}=$ Total number of individuals for all species enumerated

$\mathrm{s}=$ Total number of species

\subsubsection{Woody Species Richness}

Species richness index was calculated using Margalef's Richness Index as described by Clifford and Stephenson (1975).

$\mathrm{R}=\mathrm{S}-1 / \ln \mathrm{N}$

Where: $\mathrm{S}=$ Total number of species

$\mathrm{N}=$ Total number of individuals for all species

\subsubsection{Similarity in Species Composition between Sites}

Similarity in woody species composition between sites was calculated after Margurran (2004) using Sorensen's index.

$\mathrm{SI}=2 \mathrm{a} /(2 \mathrm{a}+\mathrm{b}+\mathrm{c})$

Where:

$\mathrm{a}=$ number of species present in both Sites

$\mathrm{b}=$ number of species present in Site 1 but absent in Site 2

$\mathrm{c}=$ number of species present in Site 2 and absent in Site 1

\section{Results and Discussion}

The woody species encountered at the various sites, their habits, abundance and relative abundance, are shown in Tables 1, 2 and 3 for the Unpolluted Site, Polluted/Treated Site, and the Polluted/Untreated Site, respectively. A total of 2166 individuals belonging to 28 species and 16 families were found in the Unpolluted Site; 149 individuals belonging to 14 species and 11 families were found in the Polluted/Treated Site; while 72 individuals belonging to 7 species and 7 families were found in the Polluted/Untreated Site. Bambusa vulgaris had the highest relative abundance $(11.87 \%)$ in the Unpolluted Site while Chromolaena odorata had the highest relative abundance in both the Polluted/Treated Site (15.44\%) and Polluted/Untreated Site (23.61\%).

Tree species dominated in all the sites (Figure 2). Woody species diversity as revealed by the Shannon-Wiener index (Figure 3) was $17.52 \%$ and $38.26 \%$ higher in the Unpolluted Site than in the Polluted/Treated Site, and the Polluted/Untreated Site, respectively. Also, species richness as shown by Margalef's index (Figure 3) was $26.09 \%$ and $60.09 \%$ higher in the Unpolluted Site than in the Polluted/Treated Site, and the Polluted/Untreated Site, 
respectively. Similarity in woody species composition (Table 4) was higher between the Unpolluted Site and the Polluted/Treated Site than between the Unpolluted Site and the Polluted/Untreated Site.

Table 1. Checklist of woody plants encountered at the unpolluted site (US)

\begin{tabular}{|c|c|c|c|c|c|}
\hline S/No. & Species & Family & Habit & Abundance & $\begin{array}{l}\text { Relative } \\
\text { abundance (\%) }\end{array}$ \\
\hline 1 & Albizia zygia & Leguminosae-Mimosoideae & Tree & 55 & 2.539243 \\
\hline 2 & Alchornea cordifolia & Euphorbiaceae & Shrub & 170 & 7.848569 \\
\hline \multirow[t]{2}{*}{3} & Anthonotha & Leguminosae-Caesalpinioideae & Tree & 17 & \\
\hline & macrophylla & & & & 0.784857 \\
\hline 4 & Bambusa vulgaris & Gramineae & Tree-grass & 257 & 11.86519 \\
\hline 5 & Baphia nitida & Leguminosae-Papilionoideae & Tree & 235 & 10.84949 \\
\hline 6 & Cocos nucifera & Palmae & Tree & 4 & 0.184672 \\
\hline 7 & Dactyladenia barteri & Chrysobalanaceae & Shrub & 120 & 5.540166 \\
\hline 8 & Dialium guineense & Leguminosae-Caesalpinioideae & Tree & 120 & 5.540166 \\
\hline 9 & Elaeis guineensis & Palmae & Tree & 56 & 2.585411 \\
\hline 10 & Euphorbia sp. & Euphorbiaceae & Tree & 171 & 7.894737 \\
\hline 11 & Ficus exasperata & Moraceae & Tree & 8 & 0.369344 \\
\hline 12 & Ficus muсuso & Moraceae & Tree & 83 & 3.831948 \\
\hline 13 & Ficus trichopoda & Moraceae & Tree & 175 & 8.079409 \\
\hline \multirow[t]{2}{*}{14} & Millettia & Leguminosae-Papilionoideae & Tree & 117 & \\
\hline & macrophylla & & & & 5.401662 \\
\hline \multirow[t]{2}{*}{15} & Musanga & Moraceae & Tree & 4 & \\
\hline & cecropioides & & & & 0.184672 \\
\hline 16 & Nauclea latifolia & Rubiaceae & Shrub & 4 & 0.184672 \\
\hline 17 & Newbouldia laevis & Bignoniaceae & Tree & 7 & 0.323176 \\
\hline 18 & Olax subscorpioidea & Olacaceae & Tree & 24 & 1.108033 \\
\hline \multirow[t]{2}{*}{19} & Pentaclethra & Leguminosae-Mimosoideae & Tree & 81 & \\
\hline & macrophylla & & & & 3.739612 \\
\hline 20 & Polyalthia sp. & Annonaceae & Tree & 26 & 1.200369 \\
\hline \multirow[t]{2}{*}{21} & Pterocarpus sp. & Leguminosae- Papilionoideae & Tree & 41 & \\
\hline & & & & & 1.892890 \\
\hline \multirow[t]{2}{*}{22} & Pycnanthus & Myristicaceae & Tree & 41 & \\
\hline & angolensis & & & & 1.892890 \\
\hline 23 & Syzygium sp. & Myrtaceae & Tree & 14 & 0.646353 \\
\hline 24 & Treculia africana & Moraceae & Tree & 56 & 2.585411 \\
\hline 25 & Uapaca heudelotii & Euphorbiaceae & Tree & 35 & 1.615882 \\
\hline 26 & Uapaca sp. & Euphorbiaceae & Tree & 20 & 0.923361 \\
\hline 27 & Vitex grandifolia & Verbenaceae & Tree & 143 & 6.602031 \\
\hline \multirow[t]{2}{*}{28} & Vitex $s p$ & Verbenaceae & Tree & 82 & 3.785780 \\
\hline & & & Total & 2166 & 100 \\
\hline
\end{tabular}


Table 2. Checklist of woody plants encountered at the polluted and treated site (PTS)

\begin{tabular}{|c|c|c|c|c|c|}
\hline S/No. & Species & Family & Habit & Abundance & $\begin{array}{c}\text { Relative } \\
\text { abundance } \\
(\%)\end{array}$ \\
\hline \multirow[t]{2}{*}{1} & Alchornea & Euphorbiaceae & Shrub & 6 & \\
\hline & cordifolia & & & & 4.026846 \\
\hline 2 & Bambusa vulgaris & Gramineae & Tree-grass & 17 & 11.4094 \\
\hline 3 & Baphia nitida & Leguminosae-Papilionoideae & Tree & 19 & 12.75168 \\
\hline \multirow[t]{2}{*}{4} & Chromolaena & Asteraceae & Shrub & 23 & \\
\hline & odorata & & & & 15.43624 \\
\hline 5 & Dacryodes edulis & Burseraceae & Tree & 5 & 3.355705 \\
\hline 6 & Dialium guineense & Leguminosae-Caesalpinioideae & Tree & 11 & 7.38255 \\
\hline 7 & Elaeis guineensis & Palmae & Tree & 7 & 4.697987 \\
\hline 8 & Euphorbia sp. & Euphorbiaceae & Tree & 3 & 2.013423 \\
\hline 9 & Ficus exasparata & Moraceae & Tree & 13 & 8.724832 \\
\hline 10 & Mangifera indica & Anacardiaceae & Tree & 5 & 3.355705 \\
\hline \multirow[t]{2}{*}{11} & Musanga & Moraceae & Tree & 1 & \\
\hline & cecropioides & & & & 0.671141 \\
\hline 12 & Newbouldia laevis & Bignoniaceae & Tree & 17 & 11.4094 \\
\hline 13 & Polyalthia sp. & Annonaceae & Tree & 3 & 2.013423 \\
\hline \multirow[t]{3}{*}{14} & Vernonia & Asteraceae & Shrub & 19 & \\
\hline & amygdalina & & & & 12.75168 \\
\hline & & & Total & 149 & 100 \\
\hline
\end{tabular}

Table 3. Checklist of woody plants encountered at the polluted and untreated site (PUS)

\begin{tabular}{|c|c|c|c|c|c|}
\hline S/No. & Species & Family & Habit & Abundance & $\begin{array}{c}\text { Relative } \\
\text { abundance } \\
(\%)\end{array}$ \\
\hline \multirow[t]{2}{*}{1} & Alchornea & Euphorbiaceae & Shrub & 1 & \\
\hline & cordifolia & & & & 1.388889 \\
\hline 2 & Bambusa vulgaris & Gramineae & Tree-grass & 9 & 12.50000 \\
\hline 3 & Baphia nitida & Leguminosae-Papilionoideae & Tree & 14 & 19.44444 \\
\hline \multirow[t]{2}{*}{4} & Chromolaena & Asteraceae & Shrub & 17 & \\
\hline & odorata & & & & 23.61111 \\
\hline 5 & Dialium guineense & Leguminosae-Caesalpinioideae & Tree & 11 & 15.27778 \\
\hline 6 & Elaeis guineensis & Palmae & Tree & 13 & 18.05556 \\
\hline \multirow[t]{2}{*}{7} & Ficus exasparata & Moraceae & Tree & 7 & 9.722222 \\
\hline & & & Total & 72 & 100 \\
\hline
\end{tabular}




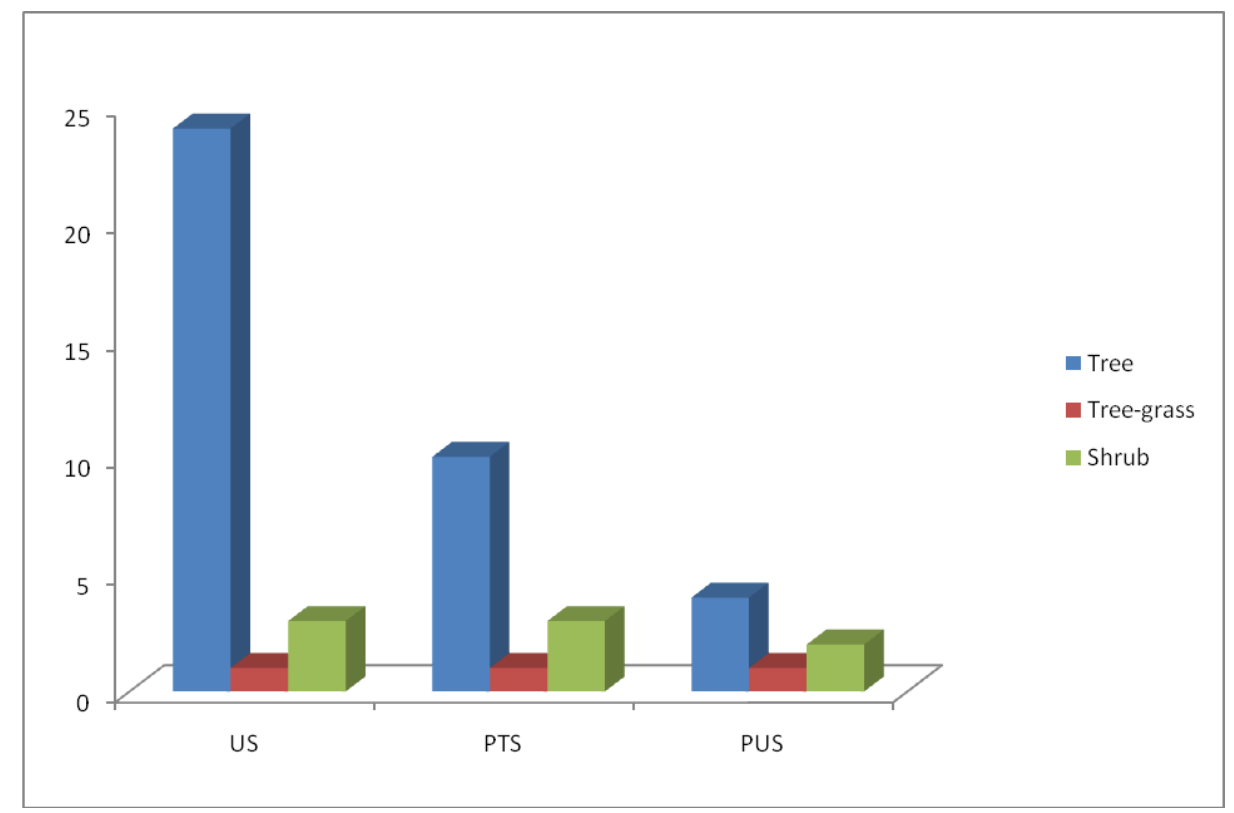

Figure 2. Habits of woody plants at different sites

US = Unpolluted Site $;$ PTS $=$ Polluted and Treated Site; PUS = Polluted and Untreated Site

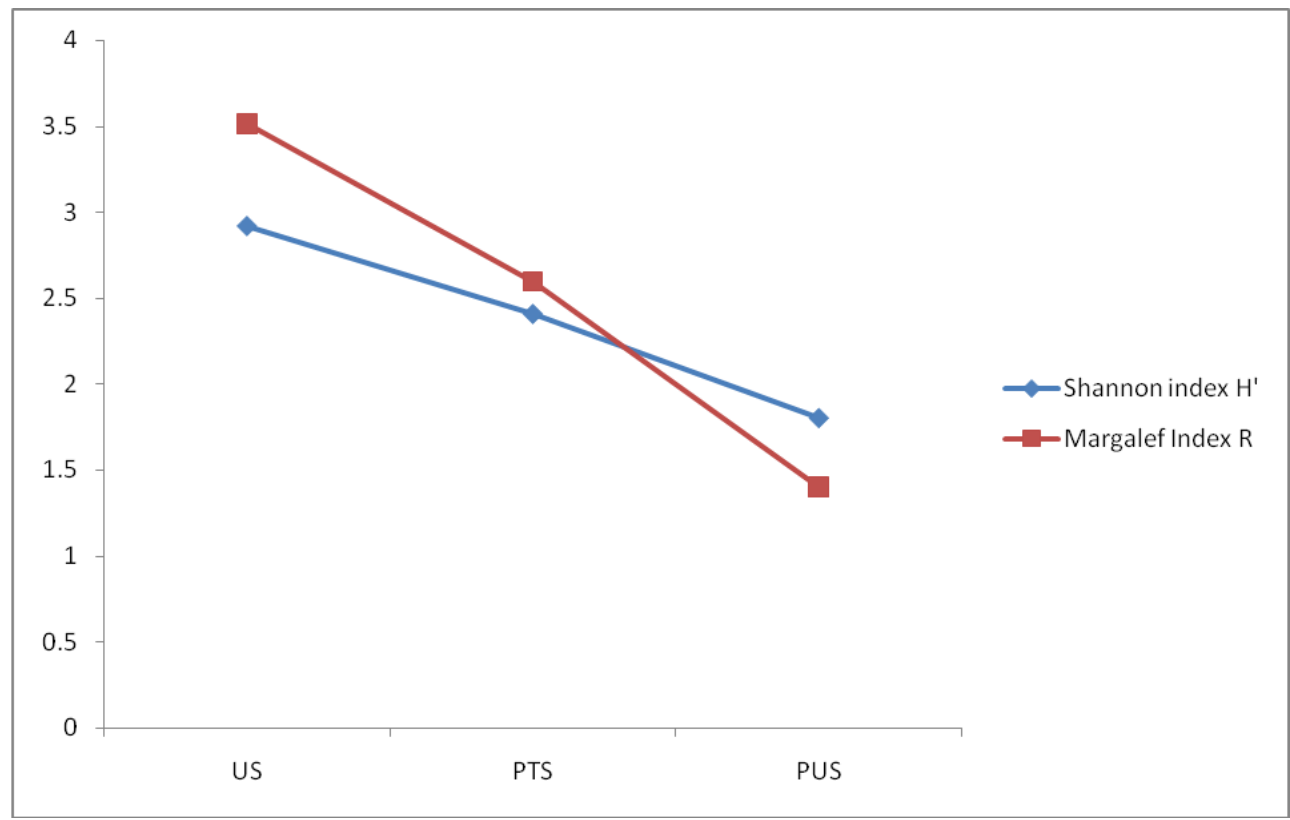

Figure 3. Woody species diversity and richness indices for different sites US = Unpolluted Site; PTS = Polluted and Treated Site; PUS = Polluted and Untreated Site 
Table 4. Sorensen Similarity indices for different sites

\begin{tabular}{cccc}
\hline & US & PTS & PUS \\
\hline US & $*$ & 0.48 & 0.34 \\
PTS & $*$ & 0.67 \\
PUS & & $*$ \\
\hline US = Unpolluted Site; PTS = Polluted and Treated Site; PUS = Polluted and Untreated Site
\end{tabular}

US = Unpolluted Site; PTS = Polluted and Treated Site; PUS = Polluted and Untreated Site

Lower species richness, diversity and abundance of woody plants in the polluted sites could be attributed to the harmful effects of crude oil. Crude oil spill has been reported to reduce species number and live standing herbaceous crop biomass (Debojit and Sarma, 1996); retard and reduce percentage seed germination, plant height, stem density, photosynthetic rate and biomass, and in most cases cause outright death of plants (Qianxin and Mendelssohn, 1996; Pezeshki et al., 2000; Ekundayo et al., 2001; Tanee and Anyanwu, 2007; Anyanwu and Tanee, 2008). However, higher species richness, abundance and diversity of woody plants in the Polluted/Treated Site than in the Polluted/Untreated Site could be attributed to improved soil and growth conditions in the former. Tanee and Albert (2011) reported a drastic reduction in soil total hydrocarbon content and significant improvement in soil conductivity, nitrate and phosphate levels, in remediated soils within the study area.

\section{Conclusion}

The study has shown that crude oil pollution has impacted negatively on woody species of the community. However, higher species richness and diversity in PTS than in PUS, and higher similarity in species composition between US and PTS, than between US and PUS, underscores the relevance of proper remediation for the regeneration and restoration of the woody species of the area.

\section{References}

Adam, G. I., \& Duncan, H. (2002). Influence of diesel on seed germination. Environmental Pollution, 120, 363-370. http://dx.doi.org/10.1016/S0269-7491(02)00119-7

Adeyemo, A. M. (2008). Environmental Policy Failure in Nigeria and the Tragedy of Underdevelopment of the Niger Delta Region. University of Port Harcourt Inaugural Lecture Series, No. 63, 114.

Anyanwu D. I., \& Tanee, F. B. G. (2008). Tolerance of cassava (Var. TMS 30572) to different concentrations of post-planting crude oil pollution. Nigerian Journal of Botany, 21, 203-207.

Clifford, H. T., \& Stephenson, W. (1975). An Introduction to Numerical Classification. London: Academic Press. 
Debojit B., \& Sarma, S. K. (1996). Impact of crude oil pollution on species number and live standing herbaceous crop biomass. The Environmentalist, 16, 291-295. http://dx.doi.org/10.1007/BF02239655

Dorn, P. H., \& Salanitro, J. (2000). Temporal ecology assessment of oil contaminated soils before and after bioremediation Chemosphere, 40(4), 419-426. http://dx.doi.org/10.1016/S0045-6535(99)00304-5

Ekundayo E. O., Emede T. O., \& Osayande D. I. (2001). Effects of crude oil spillage on growth and yield of maize (Zea mays L.) in soils of midwestern Nigeria. Plant Foods for Human Nutrition, 56, 313-324. http://dx.doi.org/10.1023/A:1011806706658

Hutchinson, J., \& Dalziel, J. M. (1954). Flora of West Tropical Africa. London: Millbank.

Keay, R. W. J. (1989). Trees of Nigeria. Oxford: Clarendon Press.

Kent, M., \& Coker, P. (1992). Vegetation Description and Analysis: A Practical Approach, London: CRC press.

Magurran A. E. (2004). Measuring Biological Diversity. Oxford: Blackwell Publishing.

Michel, J. Henry, J. R., C. B., \& Thumm, S. (2002). Shoreline assessment and environmental impacts from the M/T Westchester Oil Spill in the Mississippi River. Spill Science \& Technology Bulletin, 7(3-4), 155-161. http://dx.doi.org/10.1016/S1353-2561(02)00047-6

Michel, J., Trevor, G., Waldron, J., Blocksisidge, C. T., Etkin, D. S., \& Urban, R. (2005). Potentially polluting wrecks in marine waters, pp. 1-84. In Annals of the 2005 International Oil Spill Conference, Maio 16, Miami.

NDES (2001). Biological Environmental Research Report. RSUST, Port Harcourt, 46, 251.

Ogbo, E.M., Zibigha, M., \& Odogu, G. (2009). The effect of crude oil on growth of the weed (Paspalum crobiculatum L.) - phytoremediation potential of the plant, African Journal of Environmental Science and Technology, 3(9), 229-233.

Pezeshki S.R., Hester M.W., Lin Q., \& Nyman J. A. (2000). The effects of oil spill and clean-up on dominant US gulf coast marsh macrophytes: a review. Environmental Pollution, 108, 129-139. http://dx.doi.org/10.1016/S0269-7491(99)00244-4

Port Harcourt Appeal Court. (1994). Report of Case between SPDC Nigeria Limited (Appellant/Defendant) and the Kegbara-Dere People (Respondents/Plaintiffs).

Pyagbara, L. (2007). The Adverse Impacts of Oil Pollution on the Environment and Wellbeing of a Local Indigenous Community: The Experience of the Ogoni People of Nigeria. Paper presented at International Expert Group Meeting on Indigenous Peoples and Protection of the Environment, organized by the UN and Secretariat of the Permanent Forum on Indigenous Issues, held at Khabarovsk, Russian Federation, from August 27 - 29, 2007.

Qianxin L., \& Mendelssohn, I. A. (1996). A comparative investigation on the effects of 
Louisinia crude oil on the vegetation of freshwater, brackish and saltmarsh. Marine Pollution Bulletin, 32, 202-209. http://dx.doi.org/10.1016/0025-326X(95)00118-7

Salami, A. T. (2006). Monitoring Nigerian Forest with NigeriaSat-1 and other satellites, pp 28 - 61. In: Salami, A. T. (ed.). Imperatives of Space Technology for Sustainable Forest Management. Proceedings of an International Stakeholders' Workshop Sponsored by National Space Research and Development Agency (NARSDA), Abuja.

Tanee, F.B.G. and Albert, E. (2011). Post-Remediation Assessment of Crude Oil Polluted Site at Kegbara-Dere Community, Gokana L.G.A. of Rivers State, Nigeria. Journal of Bioremediation and Biodegradation, 2, 122. http://dx.doi.org/10.4172/2155-6199.1000122.

Tanee, F.B.G. and Anyanwu, D.I. (2007). Comparative studies of the growth and yield of two cassava lines (TMS 30572 and TMS 30555) in a crude oil polluted habitat. Scientia Africana, 6, 81- 84 . 